\title{
Driving a Firm's Agility and Success of Product Innovation Through Organizational Behavior: An Abstract
}

\author{
Wilert Puriwat and Danupol Hoonsopon
}

\begin{abstract}
Many studies strive to explore the role of organization agility on the success of firms. Nonetheless, the way to increase an organization's agility is not fully understood, especially in the new product development (NPD) process. Further, the outcomes of agility on the NPD process such as reducing fuzzy front end, enhancing innovativeness of firm, and improving new product performance are not yet clear. Drawing from concept of dynamic capabilities, using survey research, analyzing data with structural equation modeling, we expect that the results will help to describe how firms enhance the performance of new products through making an organization more agile.
\end{abstract}

\footnotetext{
W. Puriwat $\bullet$ D. Hoonsopon $(\square)$

Chulalongkorn University, Bangkok, Thailand

e-mail:wilert@cbs.chula.ac.th; danupol@cbs.chula.ac.th
} 